\title{
Understanding Reading Strategies of EFL Saudi Students
}

\author{
Muhammad Al Roomy ${ }^{1} \&$ Sajjadllah Alhawsawi ${ }^{1}$ \\ ${ }^{1}$ Department of English, College of Science and Health Professions, King Saud bin Abdulaziz University for \\ Health Sciences, Ministry of National Guard, Riyadh, Kingdom of Saudi Arabia \\ Correspondence: Muhammad Al Roomy \& Sajjadllah Alhawsawi, Department of English, College of Science \\ and Health Professions, King Saud bin Abdulaziz University for Health Sciences, Ministry of National Guard, \\ Riyadh, Kingdom of Saudi Arabia
}

\author{
Received: March 30, 2019 Accepted: May 6, 2019 Online Published: May 8, 2019 \\ doi: 10.5539/elt.v12n6p33 URL: https://doi.org/10.5539/elt.v12n6p33
}

\begin{abstract}
In many contexts around the world, English has become a major means of daily communication and a language for research and technology. Reading in English plays a key role in students' academic learning in many higher education contexts where English is the principal medium of instruction. This study measured reading strategies use as well as reading habits for everyday reading practices of EFL Saudi university students. For collecting data, Students completed a questionnaire and were interviewed by the two researchers. The quantitative and qualitative results yielded positive results that students were categorized as high users of reading strategies. Students employed different strategies to approach the complexity of reading texts. In addition, results indicated that there was a relationship between students' motivation toward reading, reading habits of reading practices and the way students implement different reading strategies.
\end{abstract}

Keywords: reading comprehension, reading strategies, strategic readers

\section{Introduction}

It goes without saying that reading in English plays a major role in our daily lives not only because English has become a global language, but also because English is the language of new technology, sciences and advanced research. Macaro (2003, p. 118) notices the importance of reading in a foreign language by stating that "once the learner has progressed beyond the beginner level, the vast majority of his or her input will be in the written form"

For university students where English is the main means of instruction, students need reading most. This is due to the fact that students need reading to purse their studies by gaining more skills and strategies to cope with different academic reading texts in a critical and creative way Fairbairn and Fairbairn (2001).

Krashen (2007) points out the vital role of extensive exposure to comprehensible input either through reading or listening in second language acquisition in the development of grammar, vocabulary. Coady and Huckin (1997) identify the symbiotic relationships between reading comprehension and vocabulary knowledge and how the two depend on each other. While learners rely on the repertoire of vocabulary to approach reading texts, reading comprehension is considered an important vehicle for developing vocabulary knowledge. However, building vocabulary through reading is a complex process that needs well-prepared and guided instruction (Coady \& Huckin, 1997).

Lack of consensus in conceptualizing reading and scarcity of genuine literature that address the connection between research and L2 reading instruction are among the many potential problems associated with L2 reading. Some researchers looked at reading as a final product where the focus is on meaning (Goodman, 1970; Broughton et al., 1980) or as an interactive process where the focus is on the different levels of involvement between reader, text and the activity (Snow, 2002; Koda, 2007). Mokhtari and Reichard (2004) assert that such research which looks at reading as a product cannot help in discovering the reading problems but rather researchers should examine the metacognitive awareness of students while they read. Grabe and Stroller (2011) adds that the lack of proper connection between research and L2 reading instruction as a result of overgeneralizing the results gained from the limited number of studies in L2 contexts or as students have different proficiency levels, results will limit the generalizability of claims.

Another cause of such problems has to do with how reading is taught. For example, the notion "the more you 
read, the better reader you become" is not totally accurate because if you accept this premise, we will end up with the conclusion that reading instruction is not important as students will improve their reading comprehension the same way they improve their oral skills after enough exposure to the target language, which is proven by research to be faulty (Stanovich, 1994). Another example is noted by Mokhtari and Reichard (2004) who pinpoint that reading and writing are essential and problematic to second language learners at the same time because some of the research on reading is based on some misconceptions of such learners. For instance, it is claimed that in some cultures rote memorization is given privilege over other methods in reading instruction which hinders reading development. Here it comes the need to teach explicitly learning strategies and more specifically reading strategies to students. The relationship between deploying specific language learning strategies and academic outcomes has been the focus of the L2 research over the last 40 years (Rubin, 1987; Paris \& Winogard, 1990; Griffiths \& Oxford, 2014). The efficiency of a learning strategy is based on the situation, the task force, the learners' goals and characteristics (Oxford \& Ma, 2014).

Wallace (2007) holds that effective reading includes the active and critical processes where the reader asks many questions to approach the text by implementing diverse reading skills such as prediction, skimming, scanning and finding the structure of the text. However, Wallace (1999) suggests that many researchers content the view that reading is a unitary selective process which means efficient readers do not need to learn only specific skills in order to tackle textual problems. For this reason, deploying reading strategies in a selective way is more essential than focusing on distinct skills. It is clear that there are some aspects of reading which do not improve naturally and require the interplay of cognitive and metacognitive abilities of readers to handle reading problems. Here it comes the importance of the repertoire of skills and strategies students exploit when approaching reading texts. Indeed, reading requires tapping upon a variety of skills which involve a multifarious cognitive and metacognitive process that requires more than just deriving meaning from the text (Lai et al., 200). The efficiency of a learning strategy is based on the situation, the task and the learners' goals (Oxford \& Ma, 2014).

Therefore, the aim of this study is to investigate Saudi students' awareness of cognitive and metacognitive reading strategies of freshmen medical students before joining the college and to connect them with their reading habits and everyday reading experiences. The findings will help understand the reading strategies deployed by these students and also device more effective way enable students to become efficient readers.

\section{Literature Review}

\subsection{Definition of Reading}

In order to comprehend the notion of reading strategies, one needs to unpack the notion and attempt to clarify what does reading could mean and what strategies could refer to. At some level, reading can be viewed in simple ways such as "reading is to say a bunch of words", "reading is what you read with your mouth" "reading is to read aloud" and so on. However, the concept of reading is more sophisticated than this and researchers had a long debate in trying to define reading. While others limit reading to just extracting meaning from printed or written materials I e., viewing reading as a reaction (Goodman, 1970; Broughton et al., 1980). Such simple definition has been characterized for not accounting for the true nature of reading abilities such as reasons and levels of engagement, the complex processes of competence and the role of social context in interpreting different context (Grabe \& Stroller, 2011). Some define reading in a more dynamic way and focus on the involvement and interaction between the reader, the text and the activity (Snow, 2002; Koda, 2007). With this in mind, it can be said that instead of viewing reading as a product which relates to what the reader has got on given comprehension tasks, it is best to be viewed as a dynamic process which includes how the reader reached a particular interpretation (Alderson \& Urquhart, 1984). The process of interaction implies that meanings of texts are mediated via connecting the existing knowledge with what the reader already knows about the text because texts do not have meaning themselves but they have possibility for meanings (Wallace, 1999). As reading is viewed as a dynamic process not just a final product, it means that the process of reading calls for a wide range of strategies of which most inefficient readers are unaware.

\subsection{Definition of Reading Strategies}

Reading comprehension strategies are "an intentional plan that readers use to help themselves make sense of their reading. Strategies are flexible and can be adapted to meet the demands of the reading task. Good readers use lots of strategies to help themselves make sense of text" (Tovani, 2000). Helping students to be aware of and master diverse reading strategies allows them to be proficient and independent readers (Booth \& Swartz, 2004). Reading strategies are mind games through which readers interact with written materials in many ways. This includes planning, deciding the purpose for the reading and the selecting what to read before reading, monitoring of understanding during reading, and evaluating the reading experience (Wolfe et al., 1998; Meniado, 2016). For 
example when reading short or long reading professional readers often involve in different process that include previewing the written materials and approach them with the right mind set. Through their reading process these readers keep connecting skilfully and automatically what they are reading to their previous knowledge and experience. This suggests that when these readers encounter challenges during the reading they often consciously resort to different mental techniques to help them identify the sources of the confusion and address it accordingly. Such sort of techniques and mental negotiation are known as reading strategies and involve various process (Alexander \& Jetton, 2000).

\subsection{Classifying of Reading Strategies}

The debate about reading strategies is very long as many scholars categorize them in various ways. For example, Oxford (1990) distinguishes between six different types of reading strategies. These are cognitive, memory, compensation, metacognitive, affective and social strategies. The cognitive strategies are used to manipulate the language and this includes note taking, summarizing, prediction and utilizing context clues. The memory ones include strategies that help with remembering and retrieving information. Techniques that help with inferencing, guessing and using dictionaries are all part of the compensation strategies. When learns use techniques to help them with learning how to plan, arrange and evaluate their reading it means that are relying on metacognitive strategies. Affective strategies refer to techniques used by learners to self-encourage themselves; and lower their anxiety. The final set of strategies are the social ones and those involve cooperation with other individuals such as working with peers, questioning and asking for correction, Oxford (1990).

Cognitive and metacognitive could be regarded as way of classifying reading strategies (Kasemsap \& Lee, 2014). The cognitive reading strategies refer the person ability to acquire information, making sense form the context, consulting dictionaries, memorizing and repetition (O'Malley \& Chamot, 1990). Flavell (1981) argues that the focus of these strategies is on how the cognitive process happens when a person is reading. Different reading research establishes that the successful comprehension of written materials does not often happen automatically but occurs through different cogitative process. Wallace (2007) holds that effective reading includes the active and critical processes where the reader asks questions to approach the text by implementing diverse reading skills such as prediction, skimming, scanning and finding the structure of the text. Sheorey and Mokhtari (2001) argue that cognitive processes are probably the first step to comprehending written materials. Most unskilled readers often rely mostly on such strategies as they are unable to consciously reflect on their reading strategies and apply more sophisticated techniques. Later, Mokhtari and Sheorey (2002) classified reading strategies into three categories: global, problem solving, and support strategies. They developed a questionnaire called the Survey of Reading Strategies Questionnaire (SORS). It aimed at explicating how often students utilize different reading strategies. Kasemsap and Lee (2014) break down the cognitive strategies into three categories/stages. These are comprehension, memory and retrieval strategies.

Metacognitive strategies in its early definition are thought to refer to the person's intentional active ability to monitor the way they read, receive information from their reading and the way they interact with these information in order to achieve specific goals (Flavell 1976). O'Malley and Chamot (1990) view metacognitive reading strategies as higher order skills that involve planning, monitoring and evaluation while having specific goals for reading. Grabe and Stroller (2011) suggest that real difference that distinguishes metacognitive strategies is the conscious awareness about the reading processes and the ability to control these processes. Meniado (2016) explains that "In the field of reading, metacognitive strategies are those activities that make students aware of their thinking as they do reading tasks" (p. 119). In Alderson's (2000) way, metacognitive reading strategies is the "thinking about thinking". These include the conscious awareness of utilising skills such as recognizing the more important part of the text, adjusting the reading speed according to the complexity of text, using contextual clues, skimming, previewing, formulating questions, translating and taking notes.

\subsection{How Reading Strategies Affect Reading}

Competent readers who are aware of the different skills involves in metacognitive reading strategies are often able to self-regulate- the skills involve in their reading and they are able to decide when to use more/less of certain strategy and check its effectiveness as they read (Thiede et al., 2003). Pressly (2002) and Karbalaei (2010) add that skilful readers often understand that the comprehension often happens through reading activities. These readers prepare and plan well for their reading and know how to relate what they read to their prior knowledge and experience. They also know how to predict when they are reading and how to summarize what has been read. Applying reading strategies mean having the ability to self-regulate oneself when dealing with written material. Thiede et al. (2003) warn educators not be deceived by the linearity in which reading strategies are often presented. In reality these strategies do not exist often linearly and get activated one after another. Competent 
readers often apply then interactively and often unconsciously.

Learning about reading strategies and being able utilize them effectively allow readers to gain immense deal of comprehension. Karbalaei (2010) suggests that readers are able to achieve great deal of comprehension when reading a text if they are able to self-regulate themselves and apply different reading strategies. Tierney (2005) emphasises that learning how to read is a vital skill for EFL/ESL students' academic advancement as they are expected to read and comprehend large volume of written materials and utilize their understanding of these materials to achieve other goals. Mastering the art of reading by being able to consciously apply different reading strategies often allows ESL/EFL students to gain better understanding of the world and themselves and provide better opportunity for them to actively interact with written materials and subsequently achieve the desire goals of the reading. Hyland (1990) argue that reading strategies help readers "get specific detail, find the main idea or theme, learn, remember, delight, summarize and do research". Singhal (2001) adds that reading strategies are used to facilitate learning and comprehension. For example, readers can employ the memory strategies for grouping in order to facilitate the understanding and meaning of the words. Reading strategies are very important factor to analysis when come researching reading because they reveal knowledge about how readers manage their interaction with written text and how these strategies are related to text comprehension (Grabe \& Stroller, 2011). However, it should be noted that there is no good or bad reading strategies and that all depends of the readers and what they want to achieve through their reading (Oxford, 2001).

\subsection{Research on Reading Strategies}

Different research has been conducted in order to address the different aspects of reading strategies applied by the first and second language readers of English. For example, in examining differences in metacognitive and perceived usage of reading strategies among native and non-native English speaker students in a US university in the United States (US) using the three classifications of reading strategies Sheorey and Mokhtari (2001). They found that both native and non-native students express a high level of awareness of various reading strategies and that both groups express the order of importance to categories of reading strategies. They also reported that students with higher reading abilities in both groups express a comparable high degree of using cognitive and metacognitive reading strategies than students with lower reading abilities in the respective groups. In addition, the study found that native English speaker students with higher reading abilities value more supporting reading strategies in compression to students with lower reading abilities in the same group. Non-native English speaking students regardless of level of reading abilities attribute great value to supporting reading strategies.

In a study that looked at way in which college student develop their reading "Hong-Nam and Leavel" (2007) argue that there a significant correlation between reading scores and reading strategy. He suggests that reading strategy impact positive on the learners reading scores.

Qanwal and Karim (2014) applied qualitative and quantitative technics in exploring the relationship between reading strategies proficiency in understanding written text. Their findings suggest positive correlation between reading strategies and learner's ability to comprehend text.

In investigating the role that metacognitive reading strategies have on learners reading test scores, Alty and Altay (2017) used a Turkish version of Mokhtari and Richard's (2004) metacognitive awareness of reading strategies inventory. Their results indicate no significant correlation between reading strategies applied by the student and their scores in tests and that the use of specific reading strategies does not necessarily lead to higher or lower achievement in reading test.

In attempt to explore the relationship between the use of metacognitive reading strategies and reading comprehensions achievement of the EEL students in Iran, Rastlegar et al. (2017) applied range of quantitative technics to test their hypotheses. Their findings suggest that a positive and significant relationship between the use of metacognitive reading strategies and reading comprehension achievement. In addition, the findings suggest learners who are able to use metacognitive reading strategies were more successful in their reading and study their EFL programme in general in comparison to those students who don't relay much on those reading strategies.

With the Arab learners, reading strategies were explored in different studies. For example, in one study, Alsheikh and Mokhtari (2011) investigated the frequency of reading strategies used by native Arabic speakers; who were considered proficient ESL readers, when reading in Arabic and English. The findings revealed that participants triggered more reading strategies when reading in English of both problem solving strategies and supporting reading strategies than when reading in Arabic due to the difficulty and unfamiliarity of English academic texts. In another study, Malcolm (2009) investigated the reading strategies profiles of 160 Arabic-speaking medical students who were studying in English. The findings showed that while students of first year and those of low 
English proficiency reported more translating strategies, students of upper years reported more metacognitive strategies with less translation. In investing the differences in metacognitive awareness and perceived usage of specific reading strategies among first and second language readers in an English for specific purposes reading programme, Mokhtari and Reichard (2004) surveyed 141 American and 209 Moroccan college students. The findings showed that both groups demonstrated patterns of a moderate to high level of awareness about reading strategies and the way they are used despite the fact that the two groups were educated in significantly different socio-cultural settings.

In attempt to ascertain the relationship between and among metacognitive reading strategies, reading motivation, and reading comprehension performance when reading academic texts in English, Meniado (2016) surveyed 60 Saudi EFL college students using descriptive survey and descriptive correlational methods. He found the students express moderate usage of reading strategies when reading academic texts and that the Problem-Solving Strategies (PROB) is most frequently used by these students. The study also reported that the students' level of reading comprehension performance was below average. Furthermore, the study revealed a positive correlation between reading strategies and reading motivation. Surprisingly, the study denied any relationship between metacognitive reading strategies and reading comprehension and that there is no relationship between reading interest/motivation and reading comprehension.

In using content schema as a mean to improve students' reading strategies, Al Asmari and Javid (2018) suggest that having background about what is going to be read help significantly in improving the reading speed and understanding of a text for Saudi EFL university students. The study suggests that brainstorming ideas around the topic and discussing in the classroom help the students to activate their schemata. Furthermore, the study argues that strategies that the students use while-reading (such as directing students' attention to single words, main ideas, important phrases and the review the title of the reading) help improving reading comprehension.

In a study about ways in which glossed texts are used as ways to facilitate and improve reading comprehension, Alharbi (2018) argues that glossed texts that provides within it definitions, synonym or translation for unfamiliar linguistic items encourages students to use range of reading strategies. He argues that presenting students with glossed texts help reduces linguistic obscurity and increases students' comprehension. Through the experiment that was reported in the study, Alharbi (2018) suggests that students who were exposed to glossed texts were able to score much higher in recalling ideas than those students who did not get exposed to similar texts. The results of the study also suggest that students feel that they like to read such glossed materials as it helps improving their comprehension greatly.

Despite the extensive research on different aspects of second and foreign language readings, few studies have looked at differences between the general reading habits that students exhibit before joining the university and the changes that could have happened in their reading strategies while they are studying in a university pre-professional English language programme. Thus, this study aims to provide answers to the following two questions:

1)- What are the students' reading habits for everyday reading practices before joining the college?

2)- Which reading strategies are applied most by students while reading?

\section{Methodology}

To explore the research questions of this study i.e. the students' reading habits and experiences before joining the college and also understand the most frequent reading strategies applied most by students while reading academic written material, we adopted a qualitative pragmatic approach. The approach was appropriate because it gives us more room to focus on answering the research questions with getting caught up in philosophical debates about the best approach also open up for us the possibility to techniques and mothed that are traditionally associated with qualitative or quantitative paradigms (Creswell \& Poth, 2017). The participants of this study were 121 freshmen students in their second semester of a two year per-professional programme in a health science Saudi university. In addition to trying to bridge the students' gap in English between what was taught in schools and that required at the university curriculum, this two-year praogramme teaches students sciences courses (e.g. chemistry, biology, biochemistry), Islamic and Arabic courses. For purposes of confidentiality, the names of the participants, university where they were studying were omitted and replaced with a pseudonym for ethical considerations. The students' prior consent was obtained to see whether or not they were willing to participate in the study. The following statemts were in the questionnaire to tell them about their rights:

a. You don't have to take part in this research questionnaire. If you choose to take part, you may withdraw at any time. 
b. Do not write down your name.

c. Any information which you give will be used ONLY for the purpose(s) of this research project, which MAY include journal/book publications, academic conferences or seminar presentations.

d. The researcher will make every effort to preserve your identity.

e. All information you give will be treated as confidential.

The data for this study was collected using a questionnaire developed by Mokhtari and Sheorey (2002) called SORS which was specifically developed to determine reading strategies implemented by post-secondary students who were either native or non-native speakers of English.

Mokhtari and Sheorey (2002) summarise the three categories of SORS and the number of items in each category as follows:

1) Global Reading Strategies (GLOB) are those intentional, carefully planned techniques by which learners monitor or manage their reading. Such strategies include having a purpose in mind, previewing the text as to its length and organisation, or using typographical aids, and tables and figures (13 items).

2) Problem -Solving Strategies (PROB) are the actions and procedures readers use while working directly with the text. These are localised, focused techniques used when problems develop in understanding textual information. Examples of cognitive strategies include adjusting one's speed of reading when the material becomes difficult or easy, guessing the meaning of unknown words, and re-reading the text for improved comprehension (8 items).

3) Support Reading Strategies (SUP) are basically support mechanisms intended to aid the reader in comprehending the text, such as using a dictionary, taking notes, or underlining or highlighting the text to better comprehend it (9 items).

We translated the questionnaires into the students' first language (L1), Arabic, in order to ease the burden of comprehension of those who were less proficient in English and to maximise the chances of all questions being answered appropriately. MARSI instrument was administered to the students to show the number of responses for each item. Subjects responded to the items on a 5-point Likert scale, specifying their strategy use from 1 (never or almost never true of me) to 5 (always or almost always true of me). All the participants completed the SORS, descriptive statistics (included frequencies, means, standard deviations and ranks) were used thought using SPSS V.22.0.

Another tool for collecting data was a semi-structured interview carried out with some students after completing the questionnaire. The purpose of the interviews as to further explain students' responses to the questionnaire items by exploring their needs, daily reading experiences and reading habits to triangulate their answers with their responses to the questionnaire items. The data for semi-structured interviews was collected from five students we were welling to be interviewed. An interview guided developed with set of questions. Questions were designed to elicit students reading habits before joining the university, their reading habits in their own first language and the tension that may exist between their current reading strategies and their pre-university reading habits. In addition, the semi-structured interviews explore further some of the point that the participants reported unclear in the questionnaires. The data from the semi-structured interviews were analysed thematically using a six stage analysis suggested by Braun and Clarke (2006). This includes thematising the data; transcribing the interview verbatim and interpreting the data in relation to the emergent themes.

After analysing the data collected from the questionnaires and the interviews separately, we combined the analysis in order to answer our research questions thoroughly.

\section{Results and Discussion}

In data analysis, SPSS V. 22.0 was used to calculate the descriptive statistics which included mean and standard deviation for each item as well as the overall mean and standard deviation of each of the four categories. To interpret mean score, Oxford and Burry-Stocks' scales (1995) was used i.e., the high-usage level was responses of 3.5 or higher, the medium-usage level was 2.5-3.4 and low-usage level was 2.4 or lower. 
Table 1. Overall participants' responses to reading strategies

\begin{tabular}{llllllll}
\hline Total & A & B & C & D & E & MULT & BLANK \\
\cline { 2 - 7 } Mean & 1470 & 1432 & 1006 & 411 & 253 & 5 & 23 \\
Standard Deviation & 3.760656 & & & & & & \\
\hline
\end{tabular}

Overall, participants reported using the four categories (global reading strategies, problem solving reading strategies, supporting reading strategies and attitude toward reading) at a high level i.e., 3.76 which indicated that they recognized the value of using reading strategies to approach reading texts and to achieve high level of processing information when reading. None of the 33 reading strategies were used at a low usage level. 28 of the reading strategies fell into the high level usage while 5 reading strategies were reported as medium level usage. Such findings could be reflective of the high grades that the students must have achieved in high schools which is a prerequisite to study in such a pre-professional programme for health professions or it could be a reflective of having a good command in English that was evident in passing English proficiency tests that were required for joining this pre-professional programme. These speculations as supported by findings from Oxford (2003) and Sheorey and Mokhtari (2001) that suggest a positive correlation between English proficiency in L2 and the use of these reading strategies. Furthermore, Rastlegar et al. (2017) Hong-Nam and Leavel (2014) stress that there a positive correlation between reading comprehension, achievement test the usage of reading strategies. Therefore, it can be argued that the more students are proficient in English, the better users of they become.

In the following tables, participants' responses would be discussed in more details with the mean and standard deviation for each item. The date obtained from the semi structured interviews are used to support the findings from the questionnaire and deepen our understanding of the research topic.

Table 2. Participants' responses to global reading strategies

\begin{tabular}{lll}
\hline Strategy & Mean & Standard Deviation \\
\hline Glob1 Setting purpose for reading & 4.07 & 0.89 \\
Glob2 Using prior knowledge & 3.89 & 1.01 \\
Glob3 Previewing text before reading & 3.82 & 0.99 \\
Glob4 Checking how text content fits purpose & 3.57 & 0.99 \\
Glob5 Skimming to note text characteristics & 3.15 & 1.28 \\
Glob6 Determining what to read & 3.90 & 1.06 \\
Glob7 Using text features (e.g. tables) & 3.93 & 1.05 \\
Glob8 Using context clues & 4.23 & 0.94 \\
Glob9 Using typographical aids (e.g.italics) & 3.46 & 1.04 \\
Glob10 analyzing and evaluating the text & 3.03 & 1.03 \\
Glob11 checking understanding & 3.31 & 0.93 \\
Glob12 Predicting or guessing text meaning & 4.23 & 0.92 \\
Glob13 Confirming predictions & 4.00 & 0.95 \\
Overall & 3.739186 & 1.080781 \\
\hline
\end{tabular}

Based on Table 2, the mean average of global reading strategies is high. As stated in by Mokhtari and Sheorey (2002), the global reading strategies are implemented to monitor or manage the process of reading. In this component, although the mean average of the overall items was high, there were some variations with respect to the different items. these results might presuppose that the participants are aware to some extend about their usages of these reading strategies and probably able to manage these strategies when they read The highest mean average was given to deploying contextual clues and guessing meaning from context strategies. Using contextual clues such as synonyms, antonyms, definition and comparing and contrasting, students were to predict and guess 
the unknown vocabulary and approach the reading texts. Predicting of guessing meaning strategies can entail that reading is more than just knowing the meaning of individual words

Such findings were supported by students' responses to the interview. For example, in one of the interview, when a student was asked about how to tackle comprehension questions, he replied "I try to guess, the issue is not about only knowing the meanings of unknown words but also about understanding the text as a whole". Another student compared the case of reading in English with reading in Arabic to support his point of view by saying "in Arabic, I would read a text that has many new words, words that I do not really understand its exact meanings, but I carry on because I still understand the text in general or resort to my background knowledge". In another reply, a student's response to the interview justified the need and the importance to use contextual clues when reading by saying "some of the words have many other meanings other than the one I know, and not knowing the meanings of these meanings might hinder my understanding of the text". Finally, Items 5 and 10 received the lowest mean average i.e. skimming for text characteristics and evaluating the read text. That was not surprising because in strategy 10 there was a need to critical thinking in order to take a step further to go in depth and evaluate the text. However, in strategy 5 students did not make use of text characteristics to generally locate information and get the main ideas before starting analyzing the text. Without having the ability to bring different parts of the text together, it is impossible to thing in a critical way and therefore gets a better and deeper understanding of what is read (Chapman et al., 2003).

Good and strategic readers are proficient in using metacognitive strategies because of the direct relationship between metacognitive knowledge and reading comprehension (Dhanapala, 2010; Karbalaei, 2010). However, metacognitive strategies have direct impact on cognitive strategies in L2 learning, use or performance, which in turn has direct impact on how L2 is performed (Phakiti, 2006).

Table 3. Participants' responses to problem solving reading strategies

\begin{tabular}{lll}
\hline Strategy & Mean & Standard Deviation \\
\hline Prob1 Reading slowly and carefully & 3.93 & 1.07 \\
Prob2 Trying to stay focused on reading & 4.42 & 0.77 \\
Prob3 Adjusting reading rate & 3.91 & 1.03 \\
Prob4 Paying close attention to reading & 3.94 & 1.00 \\
Prob5 Pausing and thinking about reading & 3.64 & 1.02 \\
Prob6 Visualizing information to read & 3.65 & 1.25 \\
Prob7 Re-reading for better understanding & 4.17 & 1.11 \\
Prob8 Guessing meaning of unknown words & 4.17 & 0.98 \\
Overall & 3.978148 & 1.066801 \\
\hline
\end{tabular}

The problem solving strategies received the highest mean average, 3.97 among the other components of the questionnaire. This incorporates with findings of Alsheikh and Mokhtari (2011), and Meniado (2016) who found that problem solving strategies received the highest strategy usage. According to the statistical analysis, which implies that students leant towards believing that the best way to tackle reading failure is by handling directly its problems. The highest score was given to the strategy of trying to stay focused while reading. In quotes from the interviews, students manifested the importance of being focused and gave some ways for that. Here are some examples "reading aloud to some sentences would make brain concentrate only on the reading not with anything else", "I often tend to underline the important information to see the links between the different parts of the text". They gave the lowest score to "pausing and thinking about reading" strategy. This could be explained by students reply to "trying to stay focused on reading" strategy, which was given the highest score. It is normal if students stop and think from time to time, they would be liable to lose track of what they have read and get confused easily. 
Table 4. Participants' responses to supporting reading strategies

\begin{tabular}{lll}
\hline Strategy & Mean & Standard Deviation \\
\hline Supp1 Taking notes while reading & 3.05 & 1.35 \\
Supp2 Reading aloud when text becomes hard & 3.16 & 1.44 \\
Supp3 Underlining information in text & 3.94 & 1.14 \\
Supp4 Using reference materials & 3.26 & 1.30 \\
Supp5 Paraphrasing for better understanding & 3.65 & 1.12 \\
Supp6 finding relationship among text ideas & 3.80 & 1.07 \\
Supp7 Asking oneself questions & 3.50 & 1.15 \\
Supp8 translating from English to Arabic & 3.91 & 1.19 \\
Supp9 thinking in both languages when reading & 3.81 & 1.03 \\
Overall & 3.562268 & 1.24968 \\
\hline
\end{tabular}

Supporting reading strategies seem to have the lowest mean average among the three categories of reading strategies. The most reported strategies to be frequently used by our participants were "underling information in the text", and "translating from English to Arabic". This agrees with findings Sheorey, and Mokhtari, (2001) and Malcolm (2010) who found that some students might resort to such supporting strategies when their reading abilities or level of English in general is not up to mark. However, underlining strategy is not always a preferable technique that students resort to in the exam. One student gave this reply in the interview "in the exam, I do not undine much, I do not have time to go back and read the underlined information, I often read the passage once and start to answer". The smallest number of the mean was given to taking notes strategy. Some important strategies like 'reading aloud' and 'using reference materials' were not used very often either. By implementing supporting reading strategies, it becomes clear how students were trying to approach the read materials by viewing reading as an interactive process. In this case, reading has other dimensions that are not limited to the literal meaning of the printed words.

Table 5. Participants' responses to attitude toward reading

\begin{tabular}{lll}
\hline Strategy & Mean & Standard Deviation \\
\hline Att. 1 Reading books, short stories, magazines & 3.78 & 1.21 \\
Att. 2 Reading in English while watching movies & 3.91 & 1.26 \\
Att. 3 Reading in English leaflets and brochures & 3.92 & 1.19 \\
Overall & 3.867978 & 1.225084 \\
\hline
\end{tabular}

The above component indicates that students' motivation towards reading is high i.e., 3.86. The likelihood that students will comprehend the read materials can occur if only students are motivated to read either inside or beyond the classrooms. The impact of motivation on reading is prominent from students' replies to interviews. One student expressed his bad experience of reading something which was not worth reading; "when I come to read in English, I feel tensed up, I read very little but I spend long time till I feel fed up, because I do not see the relevance of the topic or I read something that does not interest me". On the contrary, another student showed what motivates him to read by referring to his current situation as a student who studies English for health sciences. He explained "I guess may be because I am in the field of health I feel propelled to read these books (i.e., health sciences books". McGeown et al. (2015), in their study, observe that there are positive relationship between motivation and comprehension and summarizing skills from one hand and motivation and reading speed from another hand among students. In the interviews, students supported how they improve their English by different replies. For example, one said "I build most of my vocabulary by reading signs that are written in both Arabic and English".

\section{Conclusion}

This study aims at investigating the awareness of freshmen health sciences Saudi students about cognitive and 
metacognitive reading strategies before joining a health sciences university and how their reading habits and everyday reading experiences could influence their cognitive and metacognitive reading strategies. In particular, the study investigated the preferable reading strategies applied by Saudi university students when dealing with academic reading texts. The findings of both the questionnaire and interviews suggest that students are good users of reading strategies at high level, although some strategies were more favoured by students than others. For example, students were found to employ various reading strategies for approaching read materials to identifying the main ideas, guessing meaning of context and to utilize different ways to deal with reading problems. The findings also indicated that students' motivation toward reading was high. This is expected because when students know when and how to use reading strategies that means their enthusiasm toward reading will rise. Moreover, students expressed that by using reading strategies, they were able to interact with reading passages at different levels of reading comprehension, moving from individual meanings of words level to sentence and paragraph levels and from lexical knowledge level to interpretive and evaluative levels. The reading habits in the Arabic language and the familiarity of the text have also being proven to influence the kind of the reading strategies that a student applies when approaching written texts.

This research provides reference and contributes for further research in the field of higher education and more specifically teaching reading comprehension for EFL college students. It would be worthwhile to explore the effect of deploying reading strategies with different taught courses.

\section{Acknowledgement}

We would also like to express our gratitude to the College of Sciences and Health Professions for supporting this research. In particular, we like to thank the dean of the college Dr Abdulmohsen Alkushi, the chairperson of the English language department Mr Peter Lampe, the secretary the English language department Mr Francis R Catacutan and the personal in the assessment unit in the college - Mr Raheem Tajuddin and Mr Muhammad Raza for their help and support during the process of the research. Also, we extend our appreciation to the students of the college who shared their realities and stories with us.

\section{References}

Al Asmari, A., \& Javid, C., (2018). Role of Content Schema in Reading Comprehension Among Saudi EFL Students: EFL Teachers' Perspective and Use of Appropriate Classroom Strategies. International Journal of English Linguistics, 8(4), 96. https://doi.org/10.5539/ijel.v8n4p96

Alderson, J. (2000). Assessing reading. Cambridge, UK: Cambridge University Press. https://doi.org/10.1017/CBO9780511732935

Alderson, J., \& Urquhart, A. (1984). Reading in a Foreign Language. London: Longman.

Alexander, P., \& Tamara, J. (2000). Earning From Text: A Multidimensional and Developmental Perspective. Abingdon: Routledge.

Alharbi, B. (2018). The Impact of Glossed Texts on Reading Comprehension among Tertiary Saudi Students. English Language Teaching, 11(3), 153. https://doi.org/10.5539/elt.v11n3p153

Alsheikh, N., \& Mokhtari, K. (2011). An Examination of the Metacognitive Reading Strategies Used by Native Speakers of Arabic When Reading in English and Arabic. English Language Teaching, 4(2), 151-160. https://doi.org/10.5539/elt.v4n2p151

Altay, I. F., \& Altay, A. (2017). The Impact of Online Reading Tasks and Reading Strategies on EFL Learners' Reading Test Scores. Journal of Language and Linguistic Studies, 13(2), 136-152.

Booth, D., \& Swartz, L. (2004). Literacy techniques: Building successful readers and writers (2nd ed.). Ontario, Canada: Pembroke Publishers Limited.

Braun, V., \& Clarke, V. (2006). Using thematic analysis in psychology. Qualitative Research in Psychology, 3(2), 77-101. https://doi.org/10.1191/1478088706qp063oa

Broughton, G., Brumfit, C. Flavell, R., Hill, P., \& Pincas, P. (1980). Teaching English as a Foreign Language. Routledge and Kegan Paul Ltd.

Chapman, W., \& Tunmer, E., (2003). Reading difficulties, reading-related self-perceptions, and strategies for overcoming negative self-beliefs. Reading \&Writing Quarterly, 19(1), 5-24. https://doi.org/10.1080/ 10573560308205

Coady, J., \& Huckin, T. (1997). Second Language Vocabulary Acquisition. Cambridge: Cambridge University Press. https://doi.org/10.1017/CBO9781139524643 
Creswell, J., \& Poth, C. (2017). Qualitative Inquiry and Research Design (International Student E dition): Choosing Among Five Approaches. SAGE Publications.

Dhanapala, K. (2010). Sir Lankan University Students' Metacognitive Awareness of L2 Reading Strategies, Journal of International Development and Cooperation, 16(1), 65-82.

Fairbairn, G., \& Fairbairn, S. (2001). Reading at University: A Guide for Students. Open University Press.

Flavell, H. (1981). Metacognitive aspects of problem solving. In L. Resnick (Ed.), The nature of intelligence (pp. 37-232). Hillsdale, NJ: Lawrence Erlbaum.

Flavell, H. (1979). Metacognition and cognitive monitoring: A new area of cognitive-developmental inquiry. American Psychologist, 34, 906-911. https://doi.org/10.1037/0003-066X.34.10.906

Goodman, K. (1970). Reading: A psycholinguistic guessing game. In H. Singer, \& R. B. Ruddel (Eds.), Theoretical Models and Processes of Reading. Newark, Del.

Grabe, W., \& Stoller, F. (2011). Teaching and Researching Reading. Longman/Pearson. https://doi.org/ 10.1002/9781405198431.wbeal1174

Griffiths, C., \& Oxford, R. (2014). The twenty-first century landscape of language learning strategies. System, 43, 1-10. https://doi.org/10.1016/j.system.2013.12.009

Hong-Nam, K., \& Leavell, G. (2007).Language learning strategy use of ESL students in an intensive English learning context. System, 34, 399-415. https://doi.org/10.1016/j.system.2006.02.002

Hyland, K. (1990). Providing productive feedback. ELT Journal, 44(4), 294-304. https://doi.org/10.1093/elt/44.4.279

Karbalaei, A., (2010). A comparison of the metacognitive reading strategies used by EFL and ESL readers. The Reading Matrix, 10(2).

Kasemsap, B., \& Lee, H. (2015). L2 reading in Thailand: Vocational college students' application of reading strategies to their reading of English texts. The Reading Matrix: An International Online Journal, 15(2), 101-117.

Koda, K. (2007). Reading and language learning: Crosslinguistic constraints on second language reading development. In K. Koda (Ed.), Reading and language learning (pp. 1-44). (Special issue of) Language Learning Supplement, 57, 1-44. https://doi.org/10.1111/0023-8333.101997010-i1

Krashen, S. (2007). Extensive reading in English as a foreign language by adolescents and young adults: A meta-analysis. International Journal of Foreign Language Teaching, 3(2), 23-29.

Lai, Y., Tung, Y., \& Luo, S. (2008). Theory of reading strategies and its application by EFL learners: Reflections on two case studies.

Macaro, E. (2003). Teaching and Learning a Second Language. Continuum.

Malcolm, M. (2010). Reading Skills: Scanning Vs. Skimming.

Malcolm, D. (2009). Reading Strategy Awareness of Arabic-Speaking Medical Students Studying in English. System, 37, 640-651. https://doi.org/10.1016/j.system.2009.09.008

McGeown, S., Duncan, L., \& Stothard, S. (2015). Exploring the relationship between adolescent's reading skills, reading motivation and reading habits. Reading and Writing, 28(4), 545-569. https://doi.org/10.1007/ s11145-014-9537-9

Meniado, J. (2016). Metacognitive Reading Strategies, Motivation, and Reading Comprehension Performance of Saudi EFL Students. English Language Teaching, 9(3), 117-129. https://doi.org/10.5539/elt.v9n3p117

Mokhtari, K., \& Reichard, C. (2004). Investigating the strategic reading processes of first and second language readers in two different cultural contexts, System, 32, 379-394. https://doi.org/10.1016/j.system.2004.04.005

Mokhtari, K., \& Sheorey, R. (2002). Measuring ESL students' awareness of reading strategies. Journal of Developmental Education, 25, 2-10.

O’Malley, J., \& Chamot, A. (1990). Learning Strategies in Second Language Acquisition. Cambridge University Press, Cambridge. https://doi.org/10.1017/CBO9781139524490

Oxford, R. (1990). Language Learning Strategies. What Every Teacher Should Know? Boston, MA: Heinle \& Publishers. 
Oxford, R. (2001). Language learning strategies. In D. Nunan, \& R. Carter (Eds.), The Cambridge guide to teaching English to speakers of other languages (pp. 166-172). Cambridge, UK: Cambridge University Press. https://doi.org/10.1017/CBO9780511667206.025

Oxford, R., \& Ma, R. (2014). A diary study focusing on listening and speaking: The evolving interaction of learning styles and learning strategies in a motivated, advanced ESL learner. System, 43, 101-113. https://doi.org/10.1016/j.system.2013.12.010

Oxford, R. (2003). Language learning styles and strategies: An overview (pp. 1-25). Learning Styles \& Strategies/Oxford.

Oxford, R., \& Burry-Stock, J. (1995). Assessing the use of language learning strategies worldwide with the ESL/EFL version of the Strategy Inventory for Language Learning (SILL). System, 23(1), 1-23. https://doi.org/10.1016/0346-251X(94)00047-A

Phakiti, A. (2006). Theoretical and pedagogical issues in ESL/EFL teaching of strategic reading. University of Sydney Papers in TESOL, 1, 19-50.

Pressley, M. (2002). Metacognition and self-regulated instruction. In A. Farstrup, \& S. Samuels (Eds.), What research has to say about reading instruction (3rd ed., pp. 291-309). Newark, DE: International Reading Association. https://doi.org/10.1598/0872071774.13

Qanwal, S., \& Karim, S. (2014). Identifying correlation between reading strategies instruction and L2 text comprehension. Journal of Language Teaching and Research, 5(5), 1019. https://doi.org/10.4304/ jltr.5.5.1019-1032

Rastlegar, M., Kermani, E. M., \& Khabir, M. (2017). The Relationship between Metacognitive Reading Strategies Use and Reading Comprehension Achievement of EFL Learners. Open Journal of Modern Linguistics, 7(02), 65.

Rubin, J. (1987). Learner Strategies: Theoretical Assumptions, Research History and Typology. In A. L. Wenden, \& J. Rubin (Eds.), Learner Strategies in Language Learning (pp. 15-30), Prentice Hall, Englewood Cliffs.

Sheorey, R., \& Mokhtari, K. (2001). Differences in the Metacognitive Awareness of Reading Strategies among Native and Non-native Speakers, System, 29, 431-449. https://doi.org/10.1016/S0346-251X(01)00039-2

Singhal, M., (2001). Reading proficiency, reading strategies, metacognitive awareness and L2 readers. The Reading Matrix, 1(1).

Snow, C. (2002). Reading for Understanding: Toward an R\&D Program in Reading Comprehension, Sanata Monica Rand Corporation.

Stanovich, K., (1994). Romance and Reality. The Reading Teacher, 47, 280-291.

Thiede, K., Anderson, M., \& Therriault, D. (2003). Accuracy of metacognitive monitoring affects learning of texts. Journal of Educational Psychology, 95(1), 663. https://doi.org/10.1037/0022-0663.95.1.66

Tierney, J. E. (Ed.). (2005). Reading strategies and practices (6th ed.). Boston, MA: Pearson Education, Inc.

Tovani, C. (2000). I read it, but I don't get it: Comprehension strategies for adolescent readers. Portland, Maine: Stenhouse Publishers.

Wallace, C. (1999). Reading. Oxford: Oxford University Press.

Wallace, M. (2007). Skills in English. Cambridge: Cambridge University Press.

Wolfe, M.., Schreiner, M., Rehder, B., Laham, D., Foltz, P., Kintsch, W., \& Landauer, T. (1998). Learning from text: Matching readers and texts by latent semantic analysis. Discourse processes, 25(2-3), 309-336. https://doi.org/10.1080/01638539809545030

\section{Copyrights}

Copyright for this article is retained by the author(s), with first publication rights granted to the journal.

This is an open-access article distributed under the terms and conditions of the Creative Commons Attribution license (http://creativecommons.org/licenses/by/4.0/). 